Cite as: Can Urol Assoc J 2021;15(7):E383. http://dx.doi.org/10.5489/cuaj.7484

\title{
Error in dosage
}

In the guideline entitled, "Canadian Urological Association guideline on androgen deprivation therapy: Adverse events and management strategies," published in in the June 2021 issue of CUA) (Citation: Kokorovic A, So Al, Serag H, et al. Can Urol Assoc J 2021;15(6):E307-22. http://dx.doi.org/10.5489/cuaj.7355), the correct dosage for cyproterone acetate in Table 4 should have been 50-100 mg orally daily. CUA/ regrets the oversight and apologizes for any inconvenience. To read the guideline, visit https://cuaj.ca/index.php/journal/article/view/7355/4942. 